\title{
Article \\ Performance Investigation on Mono-Block-Layer Build Type Solid Oxide Fuel Cells with a Vertical Rib Design
}

\author{
Siyu Lu, Man Zhang, Jie Wu and Wei Kong * \\ School of Energy and Power, Jiangsu University of Science and Technology, Zhenjiang 212003, China; \\ 18852860549@163.com (S.L.); z18362883220@163.com (M.Z.); jjt192210006@163.com (J.W.) \\ * Correspondence: wkongsofc@126.com
}

\begin{abstract}
Compared with planar-type solid oxide fuel cells (SOFCs), mono-block-layer build (MOLB)type SOFCs have additional three-phase boundaries per unit volume, and their performance is severely limited by their longer current path. To resolve this issue, a vertical rib design, which was evaluated using a numerical method, was proposed. Compared with the conventional design, the power density for the vertical rib design increased by $12.32 \%$. This is because the vertical rib design provides another short path for current, which not only reduces the ohmic loss in the cathode, but also decreases the ohmic polarization caused by the contact resistance. However, the vertical rib design hinders the transport of oxygen in the cathode and increases the concentration loss. Therefore, the vertical rib size design is crucial. Based on the influence of the vertical rib width, the vertical rib widths on the cathode and anode sides of 0.7 and $1 \mathrm{~mm}$ are recommended for different contact resistances, respectively.
\end{abstract}

Keywords: solid oxide fuel cell; interconnector; vertical rib design; oxygen transfer; ohmic loss

Citation: Lu, S.; Zhang, M.; Wu, J.; Kong, W. Performance Investigation on Mono-Block-Layer Build Type Solid Oxide Fuel Cells with a Vertical Rib Design. Energies 2022, 15, 979. https://doi.org/10.3390/en15030979

Academic Editor: Paola Costamagna

Received: 18 December 2021

Accepted: 26 January 2022

Published: 28 January 2022

Publisher's Note: MDPI stays neutral with regard to jurisdictional claims in published maps and institutional affiliations.

Copyright: (C) 2022 by the authors. Licensee MDPI, Basel, Switzerland. This article is an open access article distributed under the terms and conditions of the Creative Commons Attribution (CC BY) license (https:// creativecommons.org/licenses/by/ $4.0 /)$.

\section{Introduction}

Fuel cells have attracted widespread attention from international scholars owing to their high efficiency, cleanliness, and quietness [1-4]. At present, the relatively mature fuel cell technology is the proton exchange membrane fuel cell (PEMFC), and its application fields include automobiles, forklifts, submarines, and unmanned aerial vehicles. However, PEMFCs use precious metals as catalysts, which increases the production costs. In addition, high-purity hydrogen is required, and the storage and transportation of hydrogen is a major problem, which hinders the commercial application of PEMFCs [5-7]. Compared with the PEMFCs, solid oxide fuel cells (SOFCs) can use non-noble metals as catalysts because of their higher operating temperatures (873.15-1073.15 K). In view of this, SOFC technology has developed rapidly in recent years [8-11]. The SOFC is an all-solid structure, and thus it is more convenient to made into various structural forms. Based on the structure, the SOFC can be divided into planar type, tubular type, micro tubular type and mono-block-layer build (MOLB) type [12-15]. Conversely, owing to its corrugated anode/electrolyte/cathode, the MOLB-type type SOFC increases the total length of the three-phase boundaries and reduces the activation polarization, while the corrugated anode/electrolyte/cathode provides the fuel and air flow channel, eliminating the interconnector channel and making the SOFC more compact [16].

In recent years, many scholars have used numerical simulation methods to study the effects of various parameters and design schemes on the performance of MOLB-type SOFCs. Yang et al. established an MOLB-type SOFC model to analyze the effects of co-flow and counter-flow designs on temperature and current density, and found that the co-flow design has a more uniform temperature and current density distribution [17]. Zhang et al. compared and analyzed the difference in heat and mass conduction between planar-type SOFCs and MOLB-type SOFCs. Under the same working conditions, the temperature gradient of the MOLB-type SOFC is smaller than that of the planar-type SOFC, 
and the temperature distribution of the planar-type SOFC is more sensitive to the fuel flow rate and hydrogen mass fraction [18]. Verda et al. optimized the geometric structure parameters of the MOLB-type SOFCs to minimize entropy production. The simulation results suggest that compared with the initial design, the power density of the optimized structure has increased by approximately 11\% [19]. Mendoza-Miranda et al. discussed the influence of electrolyte thickness, inlet temperature, inlet velocity, and inlet mass fraction on entropy production. The results indicate that the irreversible entropy generation is closely related to the inlet temperature and electrolyte thickness. When the inlet temperature was $973 \mathrm{~K}$, the overall entropy production was approximately $35 \%$ less than when the inlet temperature was 873 K $[20,21]$. Stygar et al. studied the influence of the MOLB-type SOFCs geometry on the temperature distribution and heat conduction rate. It was found that two adjacent layers were cross-flow, and when one layer was counter-flow, the temperature was more uniform and the temperature gradient was smaller [22]. Mendoza-Miranda et al. considered the internal reforming of methane on the anode side and found that compared with planar-type SOFCs, MOLB-type SOFCs have higher $\mathrm{H}_{2}$ concentrations and lower average temperatures [23].

In the author's previous work, the influence of anode thickness, cathode thickness, channel height, and porosity on the performance of MOLB-type SOFCs, was investigated [12]. The study found that when the cathode thickness is $100 \mu \mathrm{m}$ and the working voltage is $0.7 \mathrm{~V}$, the cathode ohmic polarization is as high as $70 \mathrm{mV}$, accounting for $17.5 \%$ of the total polarization loss of the SOFC. To reduce the ohmic polarization in the cathode, in this study, we proposed a vertical rib design, as shown in Figure 1. In addition, the difference between the conventional design and the vertical rib design was compared and analyzed, and then the effects of the vertical rib width design on the performance of the MOLB-type SOFC were studied. Finally, the optimization of the vertical rib width for different contact resistances is discussed.

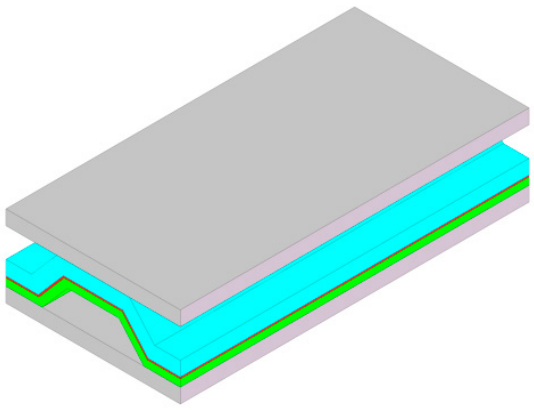

(a)

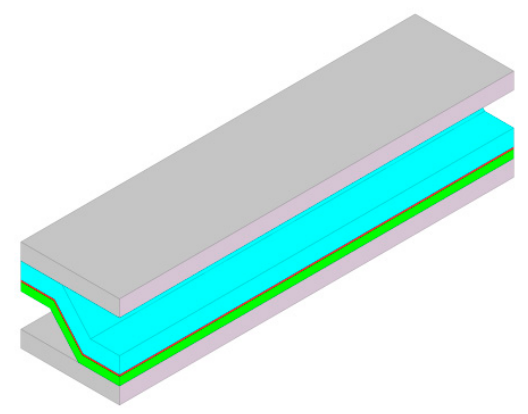

(c)

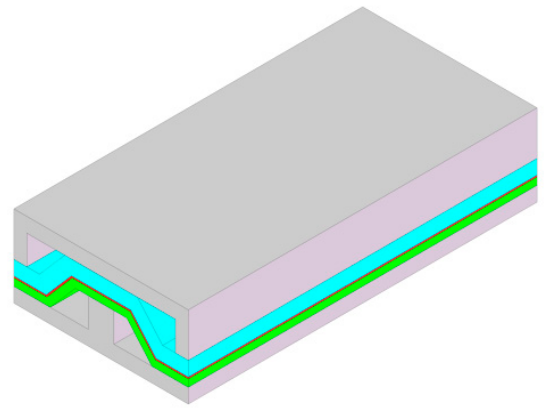

(b)

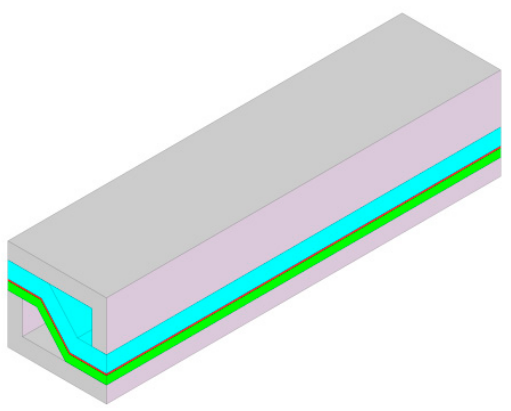

(d)

Figure 1. Cont. 


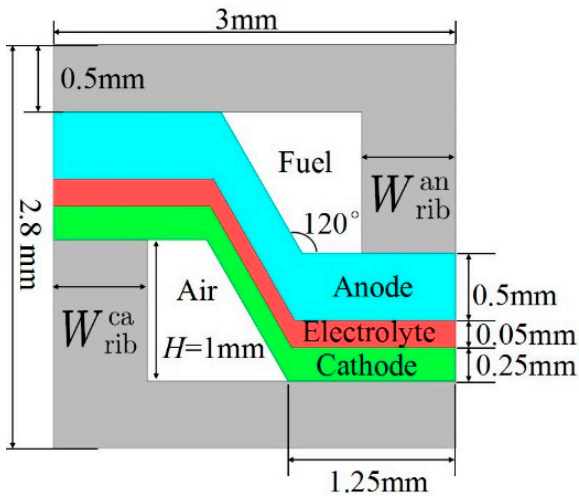

(e)

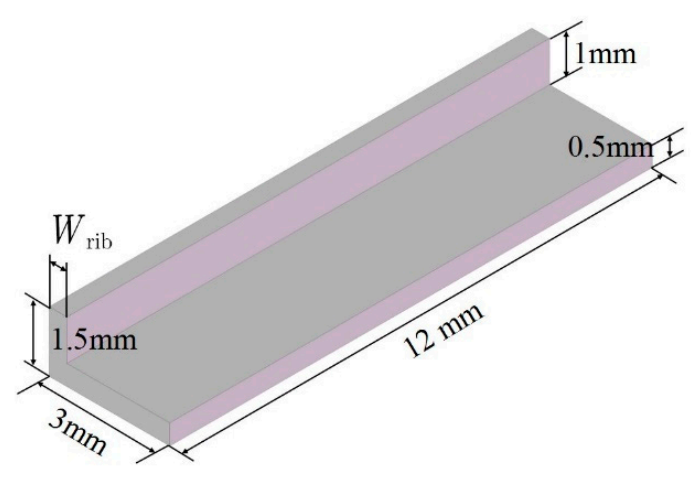

(f)

Figure 1. (a) Conventional design; (b) vertical rib design; (c) conventional design model simulation domain; (d) vertical rib design model simulation domain; (e) the size of vertical rib design; (f) vertical rib size.

\section{Model}

To shorten the simulation time, the simulation domain in this work is a repeating unit, as shown in Figure 1c,d including the interconnector (Stainless Steel), anode (Ni/YSZ), cathode (LSM/YSZ), and electrolyte (YSZ). The structural dimensions are shown in Figure 1e. The vertical rib design model is based on the conventional design model established in our previous work [12] by adding vertical ribs, and the contact resistance was set at the interface between the vertical rib and the electrode. The model is briefly introduced below, and its governing equations are listed in Table 1 . To solve the governing equations, appropriate boundary conditions must be set. The gas concentration and inlet volume flow rate were set at the channel inlet. The open-circuit voltage was set on the external surface of the anode side interconnector. The working voltage was set on the external interconnector surface of the cathode side, and the conversion current was set at the interface between the electrode and the electrolyte, as shown in Table 2. Except for the settings in Table 2, for the momentum equation, the other boundaries are no-slip, which means the normal velocity is zero; for the species equation, there is no mass flux across the other boundaries; for the charge equation, electric insulation is set on the other boundaries.

Table 1. Governing equations.

\begin{tabular}{|c|c|c|c|}
\hline & Equations & Regions & \\
\hline \multirow{2}{*}{ Momentum } & $(\rho u \cdot \nabla) u=-\nabla p+\nabla \cdot\left[\mu\left(\nabla u+(\nabla u)^{T}\right)-\frac{2}{3} \mu(\nabla \cdot u) I\right]$ & Gas channel & (1) \\
\hline & $\frac{\mu}{B_{0}}=-\nabla p+\nabla \cdot\left[\mu\left(\nabla u+(\nabla u)^{T}\right)-\frac{2}{3} \mu(\nabla \cdot u) I\right]$ & Electrode & (2) \\
\hline Mass continuity equation & $\nabla \cdot(\rho u)=0$ & Gas channel Electrode & (3) \\
\hline \multirow{2}{*}{ Species } & $\nabla \cdot N_{i}=\nabla \cdot\left(-D_{i j} \nabla C_{i}+C_{i} u\right)=0$ & Gas channel & (4) \\
\hline & $\nabla \cdot N_{i}=\nabla \cdot\left(-D_{i} \nabla C_{i}+C_{i} u\right)=0$ & Electrode & (5) \\
\hline \multirow{2}{*}{ Charge } & $\nabla \cdot i_{\mathrm{el}}=\nabla \cdot\left(-\sigma_{\mathrm{el}}^{\mathrm{eff}} \nabla \Phi_{\mathrm{el}}\right)=0$ & Electrode Interconnector & (6) \\
\hline & $\nabla \cdot i_{\text {io }}=\nabla \cdot\left(-\sigma_{\text {io }}^{\text {eff }} \nabla \Phi_{\text {io }}\right)=0$ & Electrolyte & (7) \\
\hline
\end{tabular}


Table 2. Boundary setting.

\begin{tabular}{|c|c|c|}
\hline \multicolumn{3}{|c|}{ Boundary Setting } \\
\hline \multirow{2}{*}{ Air channel inlet } & Species concentration & $C_{\mathrm{O}_{2}}=C_{\mathrm{O}_{2}}^{0} C_{\mathrm{N}_{2}}=C_{\mathrm{N}_{2}}^{0}$ \\
\hline & Volume flow & $U_{\text {air }}=3.5 \mathrm{~cm}^{3} / \mathrm{s}$ \\
\hline \multirow{2}{*}{ Fuel channel inlet } & Species concentration & $C_{\mathrm{H}_{2}}=C_{\mathrm{H}_{2}}^{0} C_{\mathrm{H}_{2} \mathrm{O}}=C_{\mathrm{H}_{2} \mathrm{O}}^{0}$ \\
\hline & Volume flow & $U_{\text {fuel }}=0.35 \mathrm{~cm}^{3} / \mathrm{s}$ \\
\hline \multirow{2}{*}{ Air channel outlet } & Outflow & $\vec{n} \cdot\left(-D_{i} \nabla C_{i}\right)=0$ \\
\hline & Pressure & $p_{\text {air }}^{\text {out }}=1 \mathrm{~atm}$ \\
\hline \multirow[b]{2}{*}{ Fuel channel outlet } & Outflow & $\vec{n} \cdot\left(-D_{i} \nabla C_{i}\right)=0$ \\
\hline & Pressure & $p_{\text {fuel }}^{\text {out }}=1 \mathrm{~atm}$ \\
\hline The cathode interconnector outer surface & Operational potential & $V_{\mathrm{op}}$ \\
\hline The anode interconnector outer surface & Nernst potential & $E_{0}$ \\
\hline \multirow[t]{2}{*}{ Anode/Electrolyte interface } & $\begin{array}{l}\text { The conversion current between the } \\
\text { electron current and the ion current }\end{array}$ & $i_{\text {trans }}^{\text {an }}$ \\
\hline & Inward flux & $\mathrm{H}_{2}:-i_{\text {trans }}^{\mathrm{an}} / 2 \mathrm{~F} ; \mathrm{H}_{2} \mathrm{O}: i_{\text {trans }}^{\mathrm{an}} / 2 \mathrm{~F}$ \\
\hline \multirow[t]{2}{*}{ Cathode/Electrolyte interface } & $\begin{array}{l}\text { The conversion current between the } \\
\text { electron current and the ion current }\end{array}$ & $i_{\text {trans }}^{\mathrm{ca}}$ \\
\hline & Inward flux & $\mathrm{O}_{2}:-i_{\text {trans }}^{\mathrm{ca}} / 2 \mathrm{~F} ; \mathrm{N}_{2}: 0$ \\
\hline Electrode/Interconnector interface & Contact resistance & $A S R_{\text {contact }}$ \\
\hline
\end{tabular}

The conversion current at the anode/electrolyte interface can be written as:

$$
i_{\text {trans }}^{\text {an }}=i_{\text {ref }}^{\text {an }} \exp \left[-\frac{E_{\mathrm{H}_{2}}}{R}\left(\frac{1}{T}-\frac{1}{T_{\text {ref }}}\right)\right]\left(\frac{p_{\mathrm{H}_{2}}^{\mathrm{TPB}} p_{\mathrm{H}_{2} \mathrm{O}}^{\mathrm{TPB}}}{p_{\mathrm{H}_{2}}^{0} p_{\mathrm{H}_{2} \mathrm{O}}^{0}}\right) \times\left[\exp \left(\frac{2 \alpha_{\mathrm{f}}^{\mathrm{an}} F}{R T} \eta_{\mathrm{act}}^{\mathrm{an}}\right)-\exp \left(-\frac{2 \beta_{\mathrm{r}}^{\text {an }} F}{R T} \eta_{\text {act }}^{\text {an }}\right)\right]
$$

The conversion current at the cathode/electrolyte can be written as:

$$
i_{\text {trans }}^{\mathrm{ca}}=i_{\mathrm{ref}}^{\mathrm{ca}} \exp \left[-\frac{E_{\mathrm{O}_{2}}}{R}\left(\frac{1}{T}-\frac{1}{T_{\text {ref }}}\right)\right]\left(\frac{p_{\mathrm{O}_{2}}^{\mathrm{TPB}}}{p_{\mathrm{O}_{2}}^{0}}\right)^{0.25} \times\left[\exp \left(\frac{2 \alpha_{\mathrm{f}}^{\mathrm{ca} F}}{R T} \eta_{\mathrm{act}}^{\mathrm{ca}}\right)-\exp \left(-\frac{2 \beta_{\mathrm{r}}^{\mathrm{ca}} F}{R T} \eta_{\mathrm{act}}^{\mathrm{ca}}\right)\right]
$$

The activation polarization of the anode can be written as:

$$
\eta_{\text {act }}^{\text {an }}=\Phi_{\text {el }}-\Phi_{\text {io }}-\frac{R T}{2 F} \ln \left(\frac{p_{\mathrm{H}_{2}}^{0}}{p_{\mathrm{H}_{2} \mathrm{O}}^{0}} \frac{p_{\mathrm{H}_{2} \mathrm{O}}^{\mathrm{TPB}}}{p_{\mathrm{H}_{2}}^{\mathrm{TPB}}}\right)
$$

The activation polarization of the cathode can be written as:

$$
\eta_{\mathrm{act}}^{\mathrm{ca}}=\Phi_{\mathrm{io}}-\Phi_{\mathrm{el}}-\frac{R T}{4 F} \ln \left(\frac{p_{\mathrm{O}_{2}}^{0}}{p_{\mathrm{O}_{2}}^{\mathrm{TPB}}}\right)
$$

This study uses Comsol Multiphisics software to establish the MOLB-type SOFC model, and the model parameters are listed in Table 3. First, the grid independence is verified for vertical rib design. Figure 2 shows grid diagrams with different grid numbers. When the number of grids was 46,200 , the power density per unit volume was $1.5502 \mathrm{~W} / \mathrm{cm}^{3}$, which was $1.5501 \mathrm{~W} / \mathrm{cm}^{3}$ for 77,000 grids. Therefore, 46,200 grids are sufficient, and the following numerical simulation uses this grid setting. To validate the model, the button cell model is built with the settings as described above except for the component thickness. The anode thickness, cathode thickness, and electrolyte thickness of the button cell model are 500, 30, and $25 \mathrm{~mm}$, respectively, according to experimental conditions in Ref [24]. Figure 3 shows a comparison between the experimental data [24] 
and model calculation results. It can be observed that the model calculation results are consistent with the experimental data.

Table 3. Model parameters [24-27].

\begin{tabular}{|c|c|}
\hline Parameters & Equations or Values \\
\hline Binary diffusion coefficient & $D_{i j}=\frac{3.198 \times 10^{-8} T^{1.75}}{p\left(v_{i}^{1 / 3}+v_{j}^{1 / 3}\right)^{2}}\left(\frac{1}{M_{i}}+\frac{1}{M_{j}}\right)^{0.5}$ \\
\hline Knudsen diffusion coefficient & $D_{i \mathrm{Kn}}=\frac{2}{3} r_{\mathrm{g}} \sqrt{\frac{8 R T}{\pi M_{i}}}$ \\
\hline $\mathrm{H}_{2}$ equivalent diffusion coefficient & $D_{\mathrm{H}_{2}}=\frac{\varepsilon}{\tau} \frac{D_{\mathrm{H}_{2} \mathrm{H}_{2} \mathrm{O}} D_{\mathrm{H}_{2} \mathrm{Kn}}}{D_{\mathrm{H}_{2} \mathrm{H}_{2} \mathrm{O}}+x_{\mathrm{H}_{2}} D_{\mathrm{H}_{2} \mathrm{OKn}}+x_{\mathrm{H}_{2} \mathrm{O}} D_{\mathrm{H}_{2} \mathrm{Kn}}}$ \\
\hline $\mathrm{H}_{2} \mathrm{O}$ equivalent diffusion coefficient & $D_{\mathrm{H}_{2} \mathrm{O}}=\frac{\varepsilon}{\tau} \frac{D_{\mathrm{H}_{2} \mathrm{H}_{2} \mathrm{O}} D_{\mathrm{H}_{2} \mathrm{OKn}}}{D_{\mathrm{H}_{2} \mathrm{H}_{2} \mathrm{O}}+x_{\mathrm{H}_{2}} D_{\mathrm{H}_{2} \mathrm{OKn}}+x_{\mathrm{H}_{2} \mathrm{O}} D_{\mathrm{H}_{2} \mathrm{Kn}}}$ \\
\hline $\mathrm{O}_{2}$ equivalent diffusion coefficient & $D_{\mathrm{O}_{2}}=\frac{\varepsilon}{\tau} \frac{D_{\mathrm{O}_{2} \mathrm{~N}_{2}} D_{\mathrm{O}_{2} \mathrm{Kn}}}{D_{\mathrm{O}_{2} \mathrm{~N}_{2}}+x_{\mathrm{O}_{2}} D_{\mathrm{N}_{2} \mathrm{Kn}}+x_{\mathrm{N}_{2}} D_{\mathrm{O}_{2} \mathrm{Kn}}}$ \\
\hline $\mathrm{N}_{2}$ equivalent diffusion coefficient & $D_{\mathrm{N}_{2}}=\frac{\varepsilon}{\tau} \frac{D_{\mathrm{O}_{2} \mathrm{~N}_{2}} D_{\mathrm{N}_{2} \mathrm{Kn}}}{D_{\mathrm{O}_{2} \mathrm{~N}_{2}}+x_{\mathrm{O}_{2}} D_{\mathrm{N}_{2} \mathrm{Kn}}+x_{\mathrm{N}_{2}} D_{\mathrm{O}_{2} \mathrm{Kn}}}$ \\
\hline Anode conductivities & $\sigma_{\mathrm{an}}^{\mathrm{eff}}=3.27 \times 10^{6}-1065.3 T\left[(1-\varepsilon) \phi_{\mathrm{an}} p_{\mathrm{el}}\right]^{3.5}$ \\
\hline Electrolyte conductivities & $\sigma_{\mathrm{el}}=3.34 \times 10^{4} \exp \left(\frac{-10300}{T}\right)$ \\
\hline Cathode conductivities & $\sigma_{\mathrm{ca}}^{\mathrm{eff}}=\frac{4.2 \times 10^{7}}{T} \exp \left(\frac{-1150}{T}\right)\left[(1-\varepsilon) p_{\mathrm{el}}\right]^{3.5}$ \\
\hline Porosity $\varepsilon$ & 0.3 cathode; 0.3 anode; \\
\hline Curvature $\tau$ & 3.5 cathode 3.5 anode; \\
\hline The diffusion volume $\left(\mathrm{m}^{3} / \mathrm{mol}\right)$ & $\begin{array}{c}16.3 \times 10^{-6} \mathrm{O}_{2} ; 18.3 \times 10^{-6} \mathrm{~N}_{2} ; 6.12 \times 10^{-6} \mathrm{H}_{2} ; \\
13.1 \times 10^{-6} \mathrm{H}_{2} \mathrm{O} ;\end{array}$ \\
\hline Permeability $\left(\mathrm{m}^{2}\right)$ & $1 \times 10^{-13} \mathrm{~m}^{2}$ cathode; $1.7 \times 10^{-10} \mathrm{~m}^{2}$ anode; \\
\hline Viscosities (Pa s) & $4 \times 10^{-5}$ air; $2.8 \times 10^{-5}$ fuel \\
\hline$T(\mathrm{~K})$ & 1073.15 \\
\hline$r_{\mathrm{g}}(\mathrm{m})$ & $5 \times 10^{-7}$ \\
\hline$\alpha_{\mathrm{f}}^{\mathrm{ca}}, \beta_{\mathrm{r}}^{\mathrm{ca}}, \alpha_{\mathrm{f}}^{\mathrm{an}}, \beta_{\mathrm{r}}^{\mathrm{an}}$ & $0.75,0.5,1,0.5$ \\
\hline$i_{\text {ref }}^{\mathrm{ca}}\left(\mathrm{A} \mathrm{m}^{-2}\right), i_{\text {ref }}^{\text {an }}\left(\mathrm{A} \mathrm{m}^{-2}\right)$ & 860,2000 \\
\hline$E_{\mathrm{O}_{2}}\left(\mathrm{~J} \mathrm{~mol}^{-1}\right), E_{\mathrm{H}_{2}}\left(\mathrm{~J} \mathrm{~mol}^{-1}\right)$ & $130 \times 10^{3}, 120 \times 10^{3}$ \\
\hline$V_{\mathrm{op}}(\mathrm{V})$ & 0.7 \\
\hline$A S R_{\text {contact }}\left(\Omega \mathrm{cm}^{2}\right)$ & 0.03 \\
\hline Gas concentration at inlet $\left(\mathrm{mol} / \mathrm{m}^{3}\right)$ & $2.38 \mathrm{O}_{2} ; 8.97 \mathrm{~N}_{2} ; 9.08 \mathrm{H}_{2} ; 2.27 \mathrm{H}_{2} \mathrm{O}$ \\
\hline
\end{tabular}

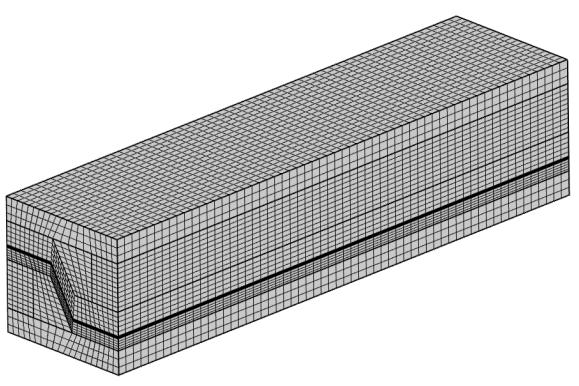

(a)

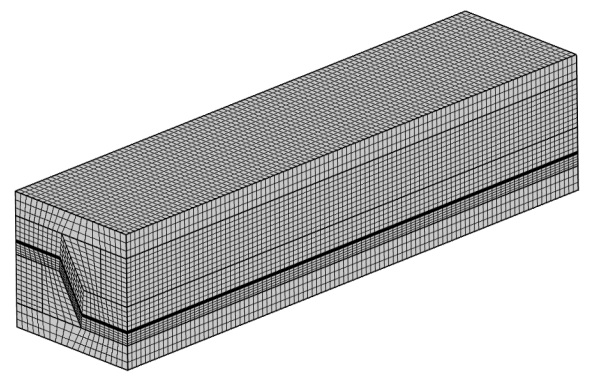

(b)

Figure 2. (a) Mesh number of 46,200; (b) mesh number of 77,000. 


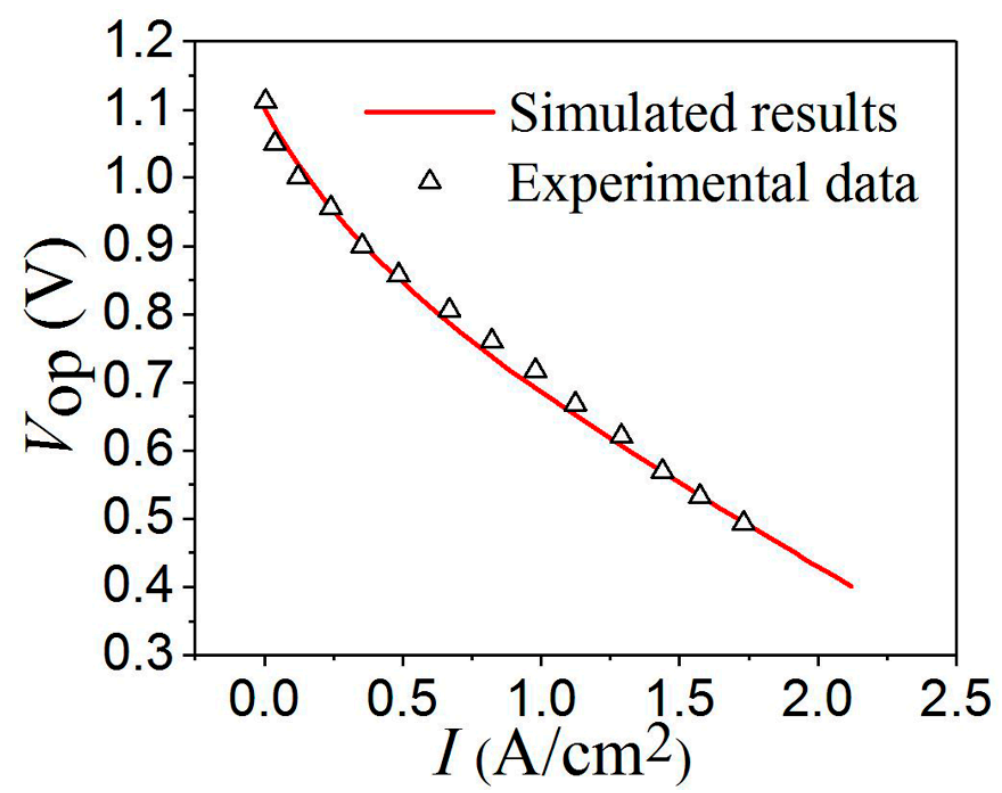

Figure 3. Model validation [24].

\section{Results and Discussion}

\subsection{Ohmic Polarization}

To reduce the ohmic polarization in the cathode, a vertical rib design was proposed. The results show that the power density for the vertical rib design is $1.55 \mathrm{~W} / \mathrm{cm}^{3}$, which increases by $12.32 \%$ from the power density of $1.38 \mathrm{~W} / \mathrm{cm}^{3}$ for the conventional design. The advantage of vertical rib design can be understood by analyzing the ohmic polarization. Figure 4 compares the cathode potential distributions of the conventional and vertical rib designs. The potential distribution is similar for the two designs, with a high potential on the left and a low potential on the right. This is because the current flows from the anode through the electrolyte to the cathode, as shown in Figure 5. In addition, the cathode ohmic polarization in the conventional design is $34.3 \mathrm{mV}(=770 \mathrm{mV}-735.7 \mathrm{mV})$, while it is only $15.2 \mathrm{mV}(=738.4 \mathrm{mV}-723.2 \mathrm{mV})$ for the vertical rib design, which is $55.7 \%$ less than the conventional design. This is because the vertical rib design provides another short path for the current and reduces the ohmic loss in the cathode.

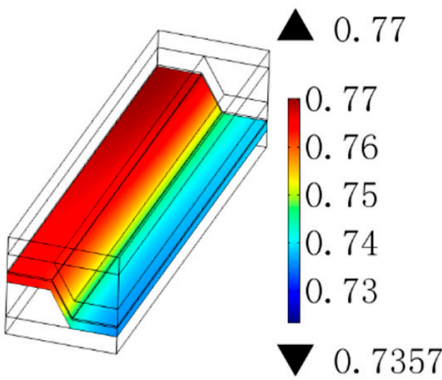

(a)

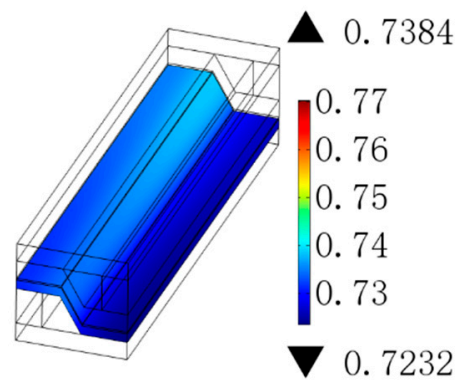

(b)

Figure 4. Cathode potential distribution: (a) conventional design: (b) vertical rib design (unit: V). 


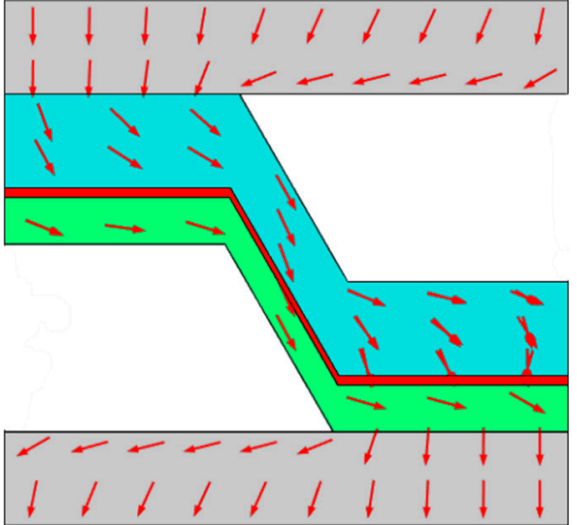

(a)

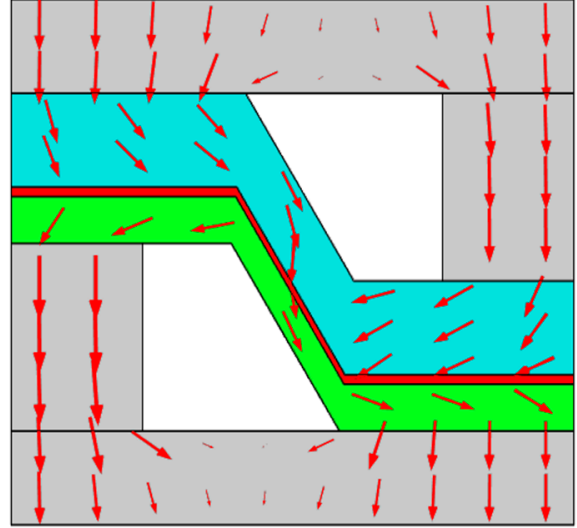

(b)

Figure 5. Current path at cross-section: (a) conventional design; (b) vertical rib design.

Figure 6 shows the potential distribution of the anodes for the two designs. Compared with the cathode, the potential change in the anode is small, which is mainly because the conductivity of the anode is much greater than that of the cathode. Owing to the generation of oxides, the interface between the interconnector and the electrode has a large contact resistance. The voltage on the upper surface of the anode interconnector is $1.1 \mathrm{~V}$, and the potential loss in the interconnector is negligible owing to its relatively large electrical conductivity. Therefore, the ohmic polarization caused by the anode contact resistance of the conventional design is $39.5 \mathrm{mV}(=1.1 \mathrm{~V}-1.0605 \mathrm{~V})$, which is $28.3 \mathrm{mV}(=1.1 \mathrm{~V}-1.0717 \mathrm{~V})$ for the vertical rib design, showing a decrease of $28.4 \%$ compared with the conventional design. The ohmic polarization caused by the cathode contact resistance is reduced from $35.7 \mathrm{mV}(=0.7357 \mathrm{~V}-0.7 \mathrm{~V})$ in the conventional design to $23.2 \mathrm{mV}(=0.7232 \mathrm{~V}-0.7 \mathrm{~V})$ in the vertical rib design, showing a decrease of $35 \%$. This is because the vertical rib design reduces the current density at the interface between the interconnector and the electrode by providing another current path, which reduces the ohmic polarization caused by the contact resistance. Therefore, the vertical rib design not only reduces the ohmic polarization in the cathode but is also beneficial to the reduction in the ohmic polarization caused by the contact resistance.

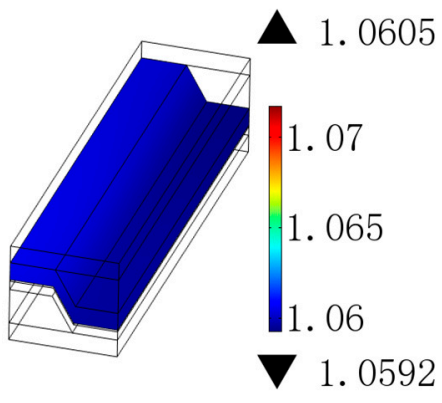

(a)

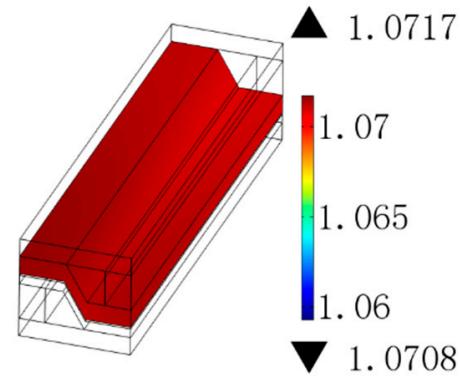

(b)

Figure 6. Anode potential distribution: (a) conventional design; (b) vertical rib design (unit: V).

\subsection{Gas Concentration Distribution}

Figure 7 shows the oxygen concentration distributions for the two designs. For both designs, the contact region between the interconnector and the cathode impedes the diffusion of oxygen in the cathode, resulting in a low oxygen concentration region, which decreases the SOFC performance. In addition, comparing Figure 7a,b it was found that the vertical rib also hindered the transport of oxygen in the cathode. On the one hand, the vertical rib design reduces the ohmic polarization, but it increases the concentration loss. Therefore, the vertical rib size design is crucial. The hydrogen concentration distributions 
are shown in Figure 8. The effects of the contact region between the interconnector and anode on hydrogen can be neglected. This is mainly because the anode thickness is thicker, which reduces the diffusion resistance of hydrogen in the horizontal direction.

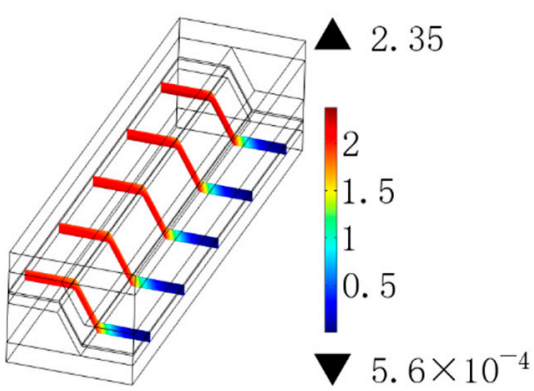

(a)

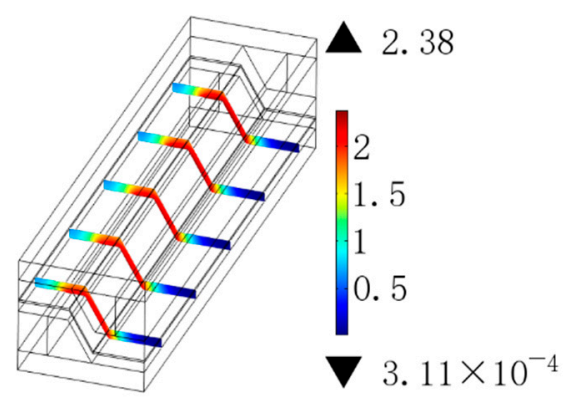

(b)

Figure 7. Oxygen concentration distribution: (a) conventional design; (b) vertical rib design (unit: $\mathrm{mol} / \mathrm{m}^{3}$ ).

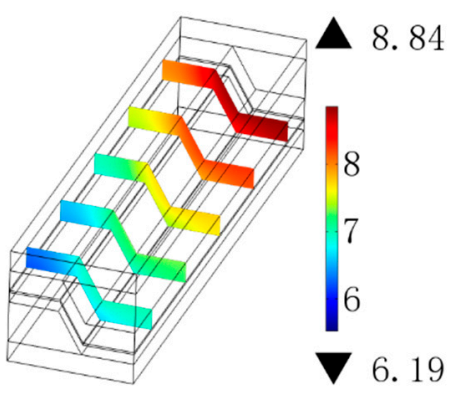

(a)

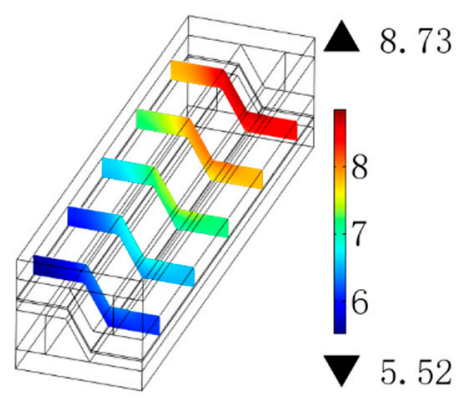

(b)

Figure 8. Hydrogen concentration distribution: (a) conventional design; (b) vertical rib design (unit mol $/ \mathrm{m}^{3}$ ).

\subsection{Vertical Rib Width}

As shown in Figure 9, ohmic loss (ohmic loss = cathode ohmic polarization + ohmic polarization introduced by anode contact resistance + ohmic polarization introduced by cathode contact resistance) gradually decreases with an increase in the vertical rib width $\left(W_{\text {rib }}\right)$, whereas the power density increases first and then decreases, reaching the maximum value when the vertical rib width $\left(W_{\text {rib }}\right)$ is $0.7 \mathrm{~mm}$. This is because an increase in the vertical rib width reduces the oxygen concentration in the cathode. For example, when the vertical rib width $\left(W_{\text {rib }}\right)$ increases from 0.1 to $0.7 \mathrm{~mm}$, the average oxygen concentration in the cathode is decreased by $16.67 \%$ from 1.44 to $1.20 \mathrm{~mol} / \mathrm{m}^{3}$. However, hydrogen is decreased by only $4.61 \%$ from 7.38 to $7.04 \mathrm{~mol} / \mathrm{m}^{3}$, as shown in Figure 9b. Therefore, the vertical rib design has a weak impact on hydrogen but has a greater impact on oxygen. Thus, it is expected that the optimal vertical rib width on the cathode side $\left(W_{\text {rib }}^{\text {ca }}\right)$ would be smaller than the optimal vertical rib width on the anode side $\left(W_{\text {rib }}^{\text {an }}\right)$. Furthermore, although with the increase in the inlet gas volume flow, the performance of SOFC is enhanced for a fixed rib width, the effect of inlet gas volume flow on the optimal vertical rib width is negligible, as shown in Figure 9c. 


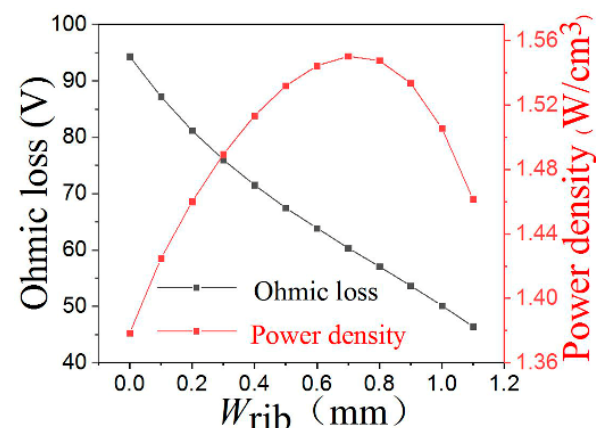

(a)

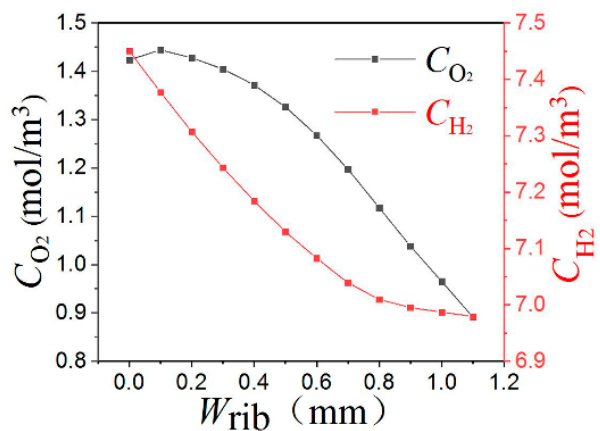

(b)

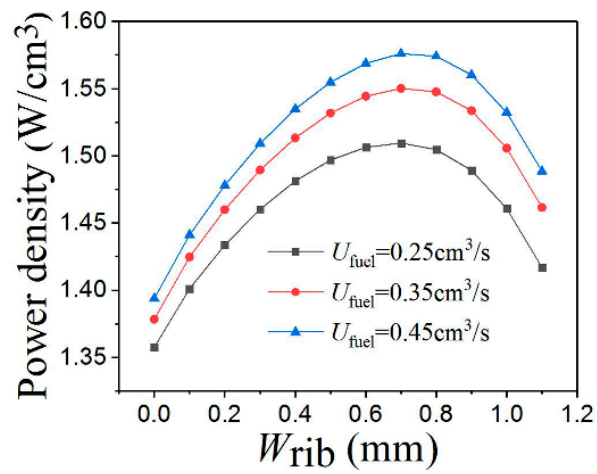

(c)

Figure 9. Influence of vertical rib width on: (a) ohmic loss and power density; (b) gas concentration; (c) the effect of inlet gas volume flow.

As mentioned above, the vertical rib design has an obvious effect on the ohmic polarization caused by the contact resistance. It is necessary to investigate the influence of the vertical rib width with different contact resistances as the contact resistance gradually increases with time. Figure 10a shows the relationship between the vertical rib width on the cathode side $\left(W_{\text {rib }}^{\text {ca }}\right)$ and the power density when the vertical rib width on the anode side $\left(W_{\mathrm{rib}}^{\mathrm{an}}\right)$ is $0.7 \mathrm{~mm}$. The greater the contact resistance, the lower the output power density. In addition, it can be observed that the smaller the contact resistance, the smaller the optimal $W_{\text {rib }}^{\mathrm{ca}}$. For example, when the contact resistance is $0.01 \Omega \mathrm{cm}^{2}$, the optimal $W_{\text {rib }}^{\mathrm{ca}}$ is $0.55 \mathrm{~mm}$, and when the contact resistance is $0.05 \Omega \mathrm{cm}^{2}$, the optimal $W_{\text {rib }}^{\mathrm{ca}}$ is $0.75 \mathrm{~mm}$. Note that the variation in the power density is small near the optimal $W_{\text {rib }}^{\text {ca }}$. Thus, an $W_{\text {rib }}^{\text {ca }}$ of $0.7 \mathrm{~mm}$ is recommended for different contact resistances.

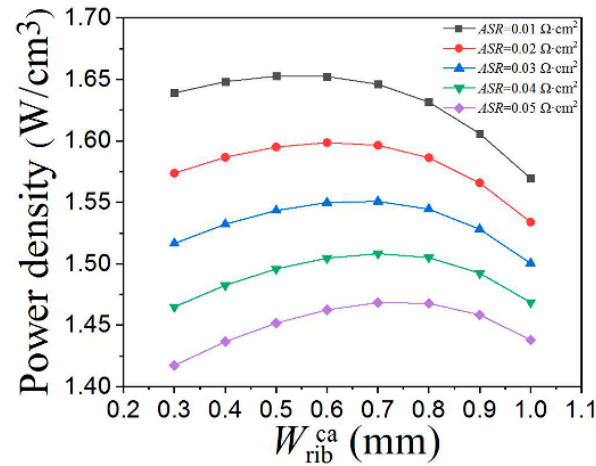

(a)

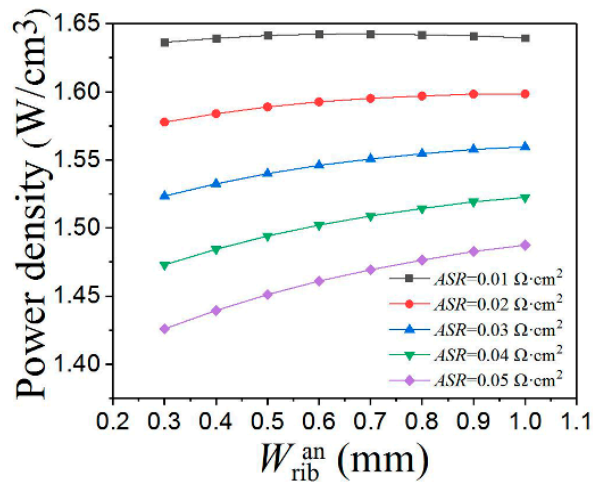

(b)

Figure 10. Influence of (a) $W_{\text {rib }}^{\text {ca }}(\mathbf{b}) W_{\text {rib }}^{\text {an }}$. 
Figure $10 \mathrm{~b}$ shows the relationship between the vertical rib width on the anode side $\left(W_{\text {rib }}^{\mathrm{an}}\right)$ and the power density for different anode contact resistances when the $W_{\text {rib }}^{\mathrm{ca}}$ is

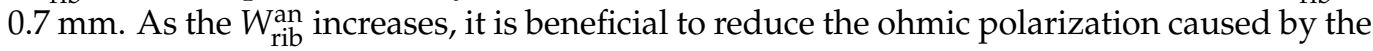
contact resistance on the anode side, but this has little effect on the hydrogen concentration. Therefore, a larger $W_{\text {rib }}^{\text {an }}$ was expected within the design range. However, owing to space constraints, an $W_{\text {rib }}^{\text {an }}$ of $1 \mathrm{~mm}$ is recommended.

\section{Conclusions}

To reduce the ohmic polarization of MOLB-type SOFCs, a vertical rib design was proposed in this study. A numerical method was adopted to analyze the advantages of the proposed design compared with the conventional design. It was found that the vertical rib design provides another additional short path for the current, reducing the ohmic polarization in the cathode, and simultaneously decreasing the ohmic polarization caused by contact resistance. However, the vertical rib design hinders the transport of oxygen and increases the concentration loss. By analyzing the influence of the vertical rib width on the cathode side $\left(W_{\text {rib }}^{\mathrm{ca}}\right)$, the results show that there is an optimal value for $W_{\text {rib }}^{\mathrm{ca}}$. Furthermore, because the anode is thicker, the vertical rib width on the anode side $W_{\text {rib }}^{\text {an }}$ has little effect on the transport of hydrogen. Therefore, a larger $W_{\text {rib }}^{\text {an }}$ was expected within the design range. However, owing to space constraints, an $W_{\text {rib }}^{\text {an }}$ of $1 \mathrm{~mm}$ is recommended.

Author Contributions: Conceptualization, W.K.; data curation, S.L.; investigation, S.L. and M.Z.; methodology, J.W.; resources, M.Z.; software, J.W.; writing-review and editing, W.K. All authors have read and agreed to the published version of the manuscript.

Funding: This research was funded by the National Science Foundation of China grant number 22179054 and 11774324. And the APC was funded by 22179054.

Institutional Review Board Statement: Not applicable.

Informed Consent Statement: Not applicable.

Data Availability Statement: Not applicable.

Conflicts of Interest: The authors declare no conflict of interest.

\section{Nomenclature}

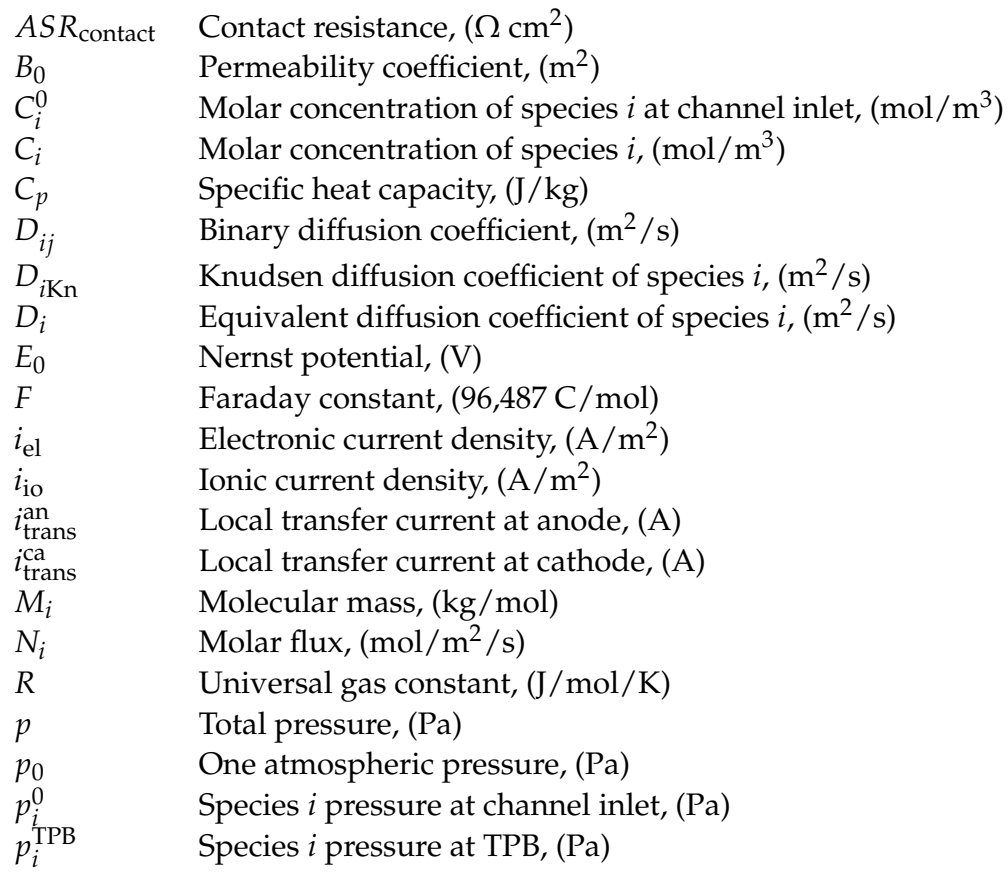




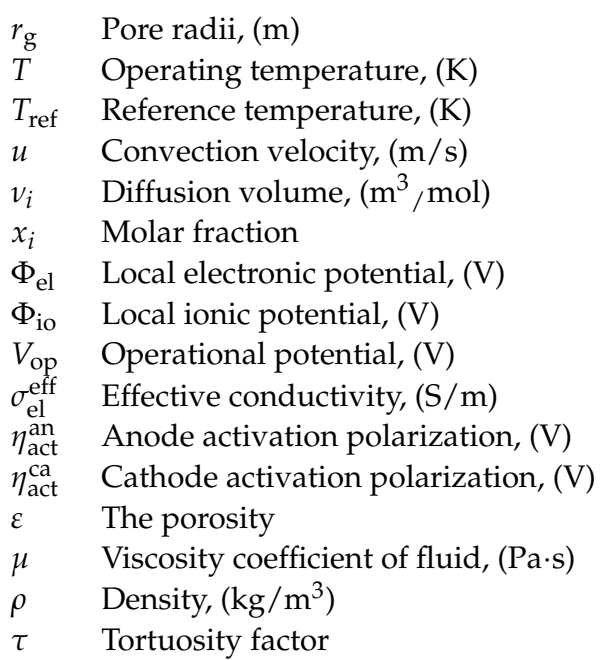

\section{References}

1. Squizzato, E.; Sanna, C.; Glisenti, A.; Costamagna, P. Structural and Catalytic Characterization of La 0.6 Sr 0.4 MnO3 Nanofibers for Application in Direct Methane Intermediate Temperature Solid Oxide Fuel Cell Anodes. Energies 2021, 14, 3602. [CrossRef]

2. Prokop, T.A.; Brus, G.; Szmyd, J.S. Microstructure Evolution in a Solid Oxide Fuel Cell Stack Quantified with Interfacial Free Energy. Energies 2021, 14, 3576. [CrossRef]

3. Nenning, A.; Bischof, C.; Fleig, J.; Bram, M.; Opitz, A.K. The Relation of Microstructure, Materials Properties and Impedance of SOFC Electrodes: A Case Study of Ni/GDC Anodes. Energies 2020, 13, 987. [CrossRef]

4. Fang, X.R.; Zhu, J.; Lin, Z.J. Effects of Electrode Composition and Thickness on the Mechanical Performance of a Solid Oxide Fuel Cell. Energies 2018, 11, 1735. [CrossRef]

5. Mao, L.; Jackson, L.; Davies, B. Investigation of PEMFC fault diagnosis with consideration of sensor reliability. Int. J. Hydrog. Energy 2018, 43, 16941-16948. [CrossRef]

6. He, K.; Zhang, C.; He, Q.B.; Wu, Q.; Jackson, L.; Mao, L. Effectiveness of PEMFC historical state and operating mode in PEMFC prognosis. Int. J. Hydrog. Energy 2020, 45, 32355-32366. [CrossRef]

7. Chang, K.Y.; Lin, H.J.; Chen, P.C. The optimal performance estimation for an unknown PEMFC based on the Taguchi method and a generic numerical PEMFC model. Int. J. Hydrog. Energy 2009, 34, 1990-1998. [CrossRef]

8. Kong, W.; Han, Z.; Lu, S.; Ni, M. A simple but effective design to enhance the performance and durability of direct carbon solid oxide fuel cells. Appl. Energy 2021, 287, 116586. [CrossRef]

9. Zhu, J.; Lin, Z.J. Degradations of the electrochemical performance of solid oxide fuel cell induced by material microstructure evolutions. Appl. Energy 2018, 231, 22-28. [CrossRef]

10. Kashmiri, S.A.; Tahir, M.W.; Afzal, U. Combustion Modeling and Simulation of Recycled Anode-off-Gas from Solid Oxide Fuel Cell. Energies 2020, 13, 5186. [CrossRef]

11. Kong, W.; Zhang, W.; Huang, H.; Zhang, Y.; Wu, J.; Xu, Y. Analysis of micro-tubular SOFC stability under ambient and operating temperatures. J. Mater. Sci. Technol. 2018, 34, 1436-1440. [CrossRef]

12. Huang, H.Y.; Han, Z.; Lu, S.Y.; Kong, W.; Wu, J.; Wang, X.R. The analysis of structure parameters of MOLB type solid oxide fuel cell. Int. J. Hydrog. Energy 2020, 45, 20351-20359. [CrossRef]

13. Fu, Q.R.; Li, Z.Y.; Wei, W.; Liu, F.X.; Xu, X.F.; Liu, Z.J. Performance enhancement of a beam and slot interconnector for anodesupported SOFC stack. Energy Convers. Manag. 2021, 241, 114277. [CrossRef]

14. Kong, W.; Han, Z.; Lu, S.Y.; Gao, X.; Wang, X.R. A novel interconnector design of SOFC. Int. J. Hydrog. Energy 2020, 45, 20329-20338. [CrossRef]

15. Altan, T.; Celik, S. Effect of surface roughness of the metallic interconnects on the bonding strength in solid oxide fuel cells. Int. J. Hydrog. Energy 2020, 45, 35118-35129. [CrossRef]

16. Hwang, J.; Chen, C.; Lai, D. Computational analysis of species transport and electrochemical characteristics of a MOLB-type SOFC. J. Power Sources 2005, 140, 235-242. [CrossRef]

17. Yang, Y.; Wang, G.; Zhang, H.; Xia, W. Computational analysis of thermo-fluid and electrochemical characteristics of MOLB-type SOFC stacks. J. Power Sources 2007, 173, 233-239. [CrossRef]

18. Yang, Y.; Wang, G.; Zhang, H.; Xia, W. Comparison of heat and mass transfer between planar and MOLB-type SOFCs. J. Power Sources 2008, 177, 426-433. [CrossRef]

19. Sciacovelli, A.; Verda, V. Entropy Generation Minimization in a Tubular Solid Oxide Fuel Cell. J. Energy Resour. Technol. Trans. Asme 2010, 132, 012601. [CrossRef]

20. Ramírez-Minguela, J.J.; Uribe-Ramírez, A.R.; Mendoza-Miranda, J.M.; Pérez-García, V.; Rodríguez-Muñoz, J.L.; Minchaca-Mojica, J.I.; Alfaro-Ayala, J.A. Study of the entropy generation in a SOFC for different operating conditions. Int. J. Hydrog. Energy 2016, 41, 8978-8991. [CrossRef] 
21. Ramírez-Minguela, J.J.; Mendoza-Miranda, J.M.; Muñoz-Carpio, V.D.; Rangel-Hernández, V.H.; Pérez-García, V.; Rodríguez-Muñoz, J.L. Internal reforming of methane in a mono-block-layer build solid oxide fuel cell with an embedding porous pipe: Numerical analysis. Energy Convers. Manag. 2014, 79, 461-469. [CrossRef]

22. Stygar, M.; Brylewski, T.; Rękas, M. Effects of changes in MOLB-type SOFC cell geometry on temperature distribution and heat transfer rate in interconnects. Int. J. Heat Mass Transf. 2012, 55, 4421-4426. [CrossRef]

23. Ramírez-Minguela, J.J.; Rodríguez-Muñoz, J.L.; Pérez-García, V.; Mendoza-Miranda, J.M.; Muñoz-Carpio, V.D.; Alfaro-Ayala, J.A. Solid oxide fuel cell numerical study: Modified MOLB-type and simple planar geometries with internal reforming. Electrochim. Acta 2015, 159, 149-157. [CrossRef]

24. Barzi, Y.M.; Raoufi, A.; Lari, H. Performance analysis of a SOFC button cell using a CFD model. Int. J. Hydrog. Energy 2010, 35, 9468-9478. [CrossRef]

25. Su, S.C.; Zhang, Q.; Gao, X.; Periasamy, V.; Kong, W. Effects of changes in solid oxide fuel cell electrode thickness on ohmic and concentration losss. Int. J. Hydrog. Energy 2016, 41, 16181-16190. [CrossRef]

26. Sanyal, J.; Goldin, G.M.; Zhu, H.; Kee, R.J. A particle-based model for predicting the effective conductivities of composite electrodes. J. Power Sources 2010, 195, 6671-6679. [CrossRef]

27. Liu, S.X.; Song, C.; Lin, Z.J. The effects of the interconnect rib contact resistance on the performance of planar solid oxide fuel cell stack and the rib design optimization. J. Power Sources 2008, 183, 214-225. [CrossRef] 